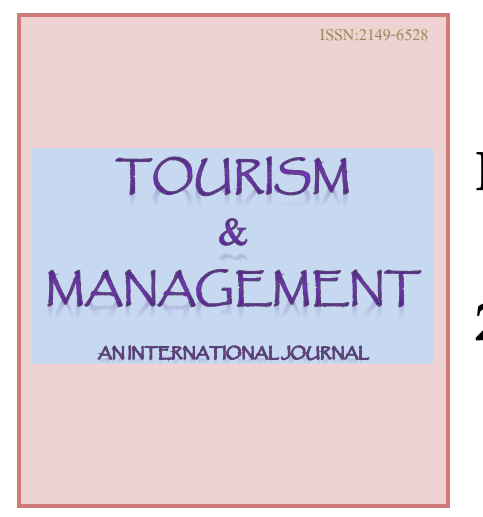

Journal of Tourism and Management Research ISSN 2149-6528

2017 Vol. 2, Issue.3

\title{
Tourism Stakeholders Attitudes Toward Sustainable Developments: Empirical Research from Shahat City
}

\begin{abstract}
This paper aims to analyse the factors affecting the stakeholders' support for sustainable tourism development in Shahat City/Libya and also identifying the tourism development trends; the attitudes, fears, as well as the hopes, those local stakeholders have concerning such developments. For this study, two versions of questionnaire were developed, one for residents and the other for tourists to solicit their perceptions about their support for sustainable tourism development in the Shahat City. A sample of 356 respondents was surveyed in this study. SPSS version 21 was used to explore the data. This study has revealed that there are results encouraging the establishment of sustainable tourism development in the Shahat City, where a very great in amount majority of the participants in the study positive trends on the development of tourism. The importance of this study stems from the increased attention in the subject of tourism and how it might contribute to raising the living standards of the population while also benefiting local societies and the environment. This study contributes to lay the groundwork for participatory sustainable development in the field of tourism in the Shahat City in the future.
\end{abstract}

Keywords: Tourism, sustainable tourism, development, stakeholders, Shahat City. JEL Classifications: L80; L83; O11

Abdelgadir, F.A.Ali. PhD student . Faculty of Economics and Business Administration, Kastamonu University. Turkey.

E-mail: Elakhwany80@gmail.com

Mine Halis. Asst.Prof.Dr. Faculty of Economics and Business Administration, Kocaeli University.

Turkey.

E-mail: minehalis@gmail.com

Muhsin Halis, Prof.Dr. (Corresponding Author). Kocaeli University, Faculty of Economics and Business Administration, Kocaeli University. Turkey

E-mail: muhsinhalis@gmail.com 


\section{Introduction}

Tourism is a key sector within the advanced and developing countries and is being utilized as a ubiquitous vehicle for economic development and diversification besides being an integral element of economic development policy (Sharpley, 2002). Tourism has become the most important source for stimulating the economies of countries of the world. It stimulates substantial investment in infrastructure and helps states to improve their balance of payments, which should assist to create job opportunities and improve the living conditions of local community by helping to equalize economic opportunities and preserve rural citizens from moving to overcrowded cities (World Tourism Organization, 2010). The rapid growth of the tourism sector makes it vulnerable to criticism by opponents of traditional development thinking that it is based on the principle of infinite growth at the expense of environmental resources (Supreme Commission for Tourism, 2001). Since the seventies, successive international development conferences in Rio de Janeiro, Copenhagen, Beijing, Cairo, and Istanbul have unanimously agreed that economic growth may succeed in raising macroeconomic indicators, but that it often causes a decline in the standard of living for many people, and can lead to the increase of poverty (Khalil, 2012). There are increase calls for the adoption of a new approaches to development in order to achieve a balance between the desires of humankind and the sustainable management of resources, which have led to the appearance of the term "sustainable development" (Mensah and Castro, 2004 ).

The term of sustainable development and its application to the tourism sector has significant consideration within the academia and has become concentration of the approach plan at all levels of government (Ruhanen and Lisa, 2006). However, several authors have noted that sustainability principles are not put into practice because economic motivations are given priority over social and environment issues (Couret, 2008). Further, scholastics have been criticized for their concern with defining and debating the definitional aspects of sustainable tourism at the expense of considering the functional perspectives, especially the development of tools for implementing the concept in practice (Kitamura and Hoshii, 2010). While the concepts of participation and strategic orientation are widely endorsed as valuable contributors to sustainable development, there have been no serious attempts to estimate the extent to which such considerations play their part in real world tourism planning processes (Ruhanen and Lisa, 2006).

Tourism has grown in some developing countries and has become the most important sector for attracting local and foreign investments, employing labour, providing income to members of the community and providing taxes to the government (General Board for Tourism and Antiquities, 2002). However, some developing countries have a comparative advantage in some of the other resources (oil for example), where the focus was on the petroleum sector - often - at the expense of other sectors. This is what happened with Libya, which now relies heavily on oil as a major source of foreign exchange earnings that contribute 95\% of total exports (Central Intelligence Agency Libya, 2006). However, in recent years, because of changes to some of the world's political and economic conditions, Libya has recognized that it needs to diversify its industry sectors in order to boost its economy (Baira, 2007). The Libyan government has recognized tourism as a key sector for development and economic diversification. With the assistance of the World Tourism Organization (WTO), it has built up the Libyan Tourism Master Plan "LTMP" (LG, 1998). This is not only taking into account the potential of tourism but also recognizes many of the problems associated with any development, such as the lack of knowledge and awareness of the Libyan hotel industry; weak infrastructure; limited tourism; limited language skills (Jwaili et al, 2004). However, there are many aspects of tourism development that are not addressed by the plan and are not covered by researchers in previous studies related to the development of tourism in Libya, In particular the study of the trends of stakeholders towards development. Stakeholder attitudes 
are very important indicators of the sustainability of tourism development and should be considered at the beginning of a development policy (Kitamura and Hoshii, 2010).

Shahat City is the area of study, located in the east of Libya, just a few kilometers from UNESCO World Heritage Site of the ancient city of Cyrene; it is a mountain city that has not received its share of development in spite of the existence of diverse tourism resources. It is in urgent need for development to find solutions too many of the city's economic, social and environmental problems and it is possible that the city's problems can be eliminated through the development of the tourism sector. This could be achieved by facilitating comprehensive and sustainable tourism development programs with the focus on small and medium enterprises that could not only create employment opportunities, but also further opportunities for the diversity and competitiveness of the area. Thus, there is a need to study stakeholders' attitudes before start on the sector development, since stakeholder support for tourism development projects will greatly contribute to the success and sustainability of such developments (Claiborne, 2010; Lepp, 2008). Therefore, the verification of the possibility of sustainable tourism development in Shahat City depends on the support of stakeholders in tourism development; the main theme of this study. This study is coming timely, because the tourism in Libya is still in discovery stage, especially in the city where there are no current programs for tourism development. The attitudes of stakeholders at this stage will put the foundation for sustainable tourism development in the City.

\section{Literature Review}

\subsection{Sustainable Tourism Development}

If the economic development was a permanent advancement factor, then this only shows a quantitative dimension. While there are consensuses among the specialists of the tourism sector that tourism, activities cannot form an economic pole unless they acquire continuity that makes them a constant factor in the economic surrounding that can drive the advancement wheel. On that subject, the report done by The United Nation Economic and social Council in 2000 mentions that; "The tourism development has to be built on an Ecological base on the long-term and on the economic and social levels of the local societies" obviously the sustainable development in its modern definition does not exclude tourism as a sensitive sector that seems to be a new global direction. Moreover, the advanced countries in the tourism sector are working on putting long-term studies and plans to create a kind of stability and establishment for this sector. Subsequently, these countries are adopting comprehensive policies that have a medium and long-term effects while avoiding the short term development plans. Therefore, we find that the development of the tourism sector by sustainable development is mentioned in agreements and pacts that have a continental and international nature. For instance, we could mention "Manila Report" which is related to heritage, where in 1988 a statement was published in it "that tourism is capable of providing the suitable conditions, and in the international research frame which was executed by the new international organization, and capable of playing a positive role in creating balance and cooperation between countries" (Social and Economic Council, 2000).

The aforementioned clearly illustrates that the view of the tourism sector has become built on the long term plans in order to create a solid base for this industry targeting its transformation to an essential factor in achieving sustainable development. The objectives of Sustainable Tourism are (Weaver and Lawton,2007):

- Protecting the local culture and its environmental, cultural and social properties (The heritage and traditions, the social and economic phenomena, and the civil and cultural levels).

- Tourist resources usage rationalization. 
- Protecting the environment from pollution (earth, climate, water, life, wildlife, population growth).

Ecotourism represents a type of tourism that is based on the concept of tourism sustainability. It also depends mainly on the nature's elements followed by the social element of the local residents who live in the tourist areas. Therefore, the sustainability is mainly related to the sustainability of the environment and the sustainability of the economy.

The observer of the ecotourism evolvement synchronicity with the world economic crisis realizes the importance of supporting this direction from an industrial and production perspectives which contributes into increasing the national income, providing employment opportunities, utilizing manpower, and achieving the development program. From the environmental perspective, ecotourism is an attraction factor for tourists and for satisfying their desires and aspirations to enjoy and visit the natural places; however, taking into consideration that this investment in environment resources does not result into draining these natural resources but should be a way to conserve and protect it for "a sustainable ecotourism". Therefore, ecotourism cannot be a development factor unless it is used to achieve a sustainable ecotourism and subsequently a sustainable development.

\subsection{Stakeholder Theory}

The theory adopted to study the subject at hand is stakeholder theory. The theory was initially designed in consonance with the needs of business management discipline, to ascertain the primary stakeholders in an organization, who are capable of winning the leadership. An initial advocate of the stakeholder theory, Freeman, suggested that managers should ideally explore a useful interaction with multiple elements, to succeed in their endeavors at managing business. (Drita and Alkida, 2009; Freeman, 1984).

The literal definition of the term 'stakeholder' is "a group of individuals, orderly or disorderly, with a shared concern, pursuit or interest in a specific problem or venture." (Grimble and Wellard, 1997). Whereas Friedman considered the term to stand for "an individual or a group of individuals who have the ability to caste impact to or get impacted by the acquisition of an organization's goals". (Friedman and Miles, 2006:47). The term 'stakeholder' has also been ascertained as "an individual, group or organization that gets impacted by the reasons or outcomes of a problem." (Bryson, et al., 2002:568).

Stakeholder theory determines the participation of several parties in the process of management inclusive of governmental organizations, political parties, local population and allied business concerns. (Sheehan and Ritchie, 2005). Stakeholder theory has been put to use productively in several frameworks including: enhancing the organizations' efficiency, enhancing the involvement of minority groups in local schemes, project management and increasing public's involvement in projects tailored for masses, e-governance, e-business and finance. Stakeholder approach includes various stages and an organization should consider its major stakeholders first, and identify their concerns and interests. It is mandatory to comprehend the process and much needed to manage the stakeholders. When an organization endeavors to ascribe resources for the use of stakeholders, problems are usually expected to emerge. (Freeman, 2010; Hann, et al., 2011; Lily, 2003).

The upcoming joint ventures are mainly "resources or interests inclusive of knowledge, financial capital, and manpower between two or more tourism stakeholders for generating avenues or resolving issues that cannot be handled with by a person alone." The tourism industry demands the improvement of tourist areas and local public, tourism companies, government and private sector should contribute to it (Fusco, et al., 2009; Selin and Chavez, 1995:189). Jamal and Getz (1995) observed that a target community's resources can be accessed by local community, visitors, and public and private sector concerns. Choibamroong, (2011) also supported the necessity to ask stakeholders for the purpose of 
growth of the tourism sector, irrespective of the objective being economic growth, protection of tourist sites, social justice or administering the secluded areas .

Steady growth of tourism at the country's level needs cooperation from the relevant stakeholder groups, specifically the local masses. Stakeholder theory has been productive in helping develop the strategic process. Working together through the participation of stakeholders is necessary for inviting cooperation for steady growth (Gnan, et al., 2010; Gracia, 2013; Wan and Xiangping, 2013). It is recommended that stakeholders should be classified into two categories:

I) Primary stakeholders, i.e. the stakeholders whose contribution to the organization ensures its existence as a going concern and,

II) Secondary stakeholders i.e. the stakeholders who impact or get impacted by the firm but are not involved in business with the firm and are not necessary for its existence.

The effectiveness of the stakeholder theory emerges from the context that effective preparation and mapping of an idea and its steady growth after realization, primarily stands on the participation of several organizations, groups and individuals who get impacted by the idea or carry the potential to influence the organizations actions. (Bashir, 2012; Byrd, 2007). For that reason, any efforts towards ensuring steady growth of tourism without involving all the stakeholder groups is a flawed approach, even after the lapse of time. For instance, Walt Disney's endeavor to design a theme park in Prince William County, Virginia in 1993 failed due to non-involvement of all stakeholder groups in the strategizing process. The team spotted local people, government representatives and entrepreneurs who facilitated their project and sought their advice during the strategy stage, but local people, tourists and other stakeholders who were not part of consulting process and hence, they were left out in the beginning, which later ended the project. (Hawkins and Cunningham, 1996). This illustration proves the risk of leaving out any stakeholder group, specifically if the group is not convinced regarding a certain project. Thus, it is instrumental to apply Freeman's Stakeholder Theory in tourism development scenarios.

\subsection{Stakeholder Analysis.}

The first stage towards applying the stakeholder theory in real life scenario is difficult yet significant. One needs to recognize the relevant stakeholder and make headway towards the suitable sample of this definite stakeholder. Caution needs to be exercised while identifying the relevant stakeholders from different categories of individuals or groups that impact or are impacted by an organization's functioning instead of a short report of the clearly most relevant stakeholders. Freeman (1984) ascertained three significant notions towards the successful administration of stakeholders:

- The recognition of stakeholders and their concerned stakes as understood;

- The procedures mandated to administer the organization's connection with its stakeholders;

- The administration of communication between the organization and relevant stakeholders.

Thus, the first stage to the efficient organization of the concerned groups is the stakeholders' recognition. Several approaches are valid to recognize relevant stakeholders employing a number of standards: the position of stakeholders relies on one major factor, whether they are the organization's regular members or not (Sautter and Leisen, 1999). In addition, their connection with the organization is from a contractual perspective or they are from the local population. It must be determined whether they are the immediate and firsthand connection, and what their commitment to collaboration is. These standards are being widely utilized to recognize and categorize people into stakeholders of a particular organization (Charkham, 1992; Clarkson, 1995; Friedman and Miles , 2006 ; Mitchell et al., 
1997; Savage et al., 1991). The categorization immensely helps in determining the significance of stakeholders for a firm that organizations must consider. In the figure 1, stakeholder relevance design is determined as most relevant and the most productive to study stakeholder precedence concerning theoretical and real life relevance and utilization. Thus, it can offer a constructive method for categorizing stakeholders and providing direction on the finest way to analyze it. An effective categorization of stakeholders was offered by Mitchell et al., (1997) on the grounds of their ability to impact, their respective authenticity, and their connection with the firm, and the exigency of the stakeholder's right to the firm. The connection between organizations and their stakeholders can be as difficult as the method to administer them. Thus, determining the significance of stakeholders to the firm and the extent of the managers' precedence to the stakeholders' demands over the firm is necessary. These factors highlight the fact that stakeholders' recognition helps understanding their belongings in stipulations of one, two or all three factors including authority, authenticity and necessity. Mitchell et al. (1997) highlighted the significance of authority in determining the connections between stakeholders. They stress that despite its immense significance, authority is usually ignored when it comes to determining stakeholders' connections. The other quality is authenticity which points towards the assertions of the stakeholders towards the firm and exigency reflects the level to which stakeholders' right over the organization would need to be addressed. (Mitchell et al., 1997).

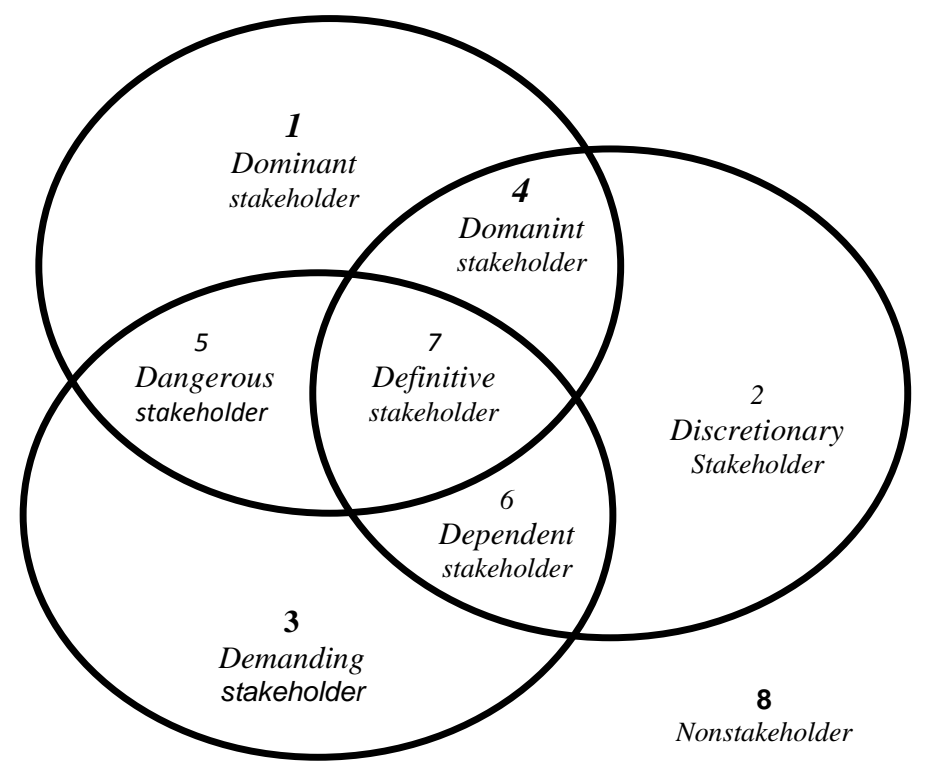

Figure 1: Salience model: stakeholders classification.

Source: Adapted from Mitchell et al. (1997:874).

Suchman (1995) describes authenticity as a common perspective, which shows hopes of a certain entity in the ambit of societal principles, ethics, standards and ideals. His description could be hard to put into practice although it carries many fine explanations, which will lead to a better understanding of who the most relevant stakeholders are. In the end, Mitchell et al (1997) suggested that the exigency gives the simulation a multifaceted approach. They stressed the fact that in the absence of exigency trait, the simulation would be stagnant for consideration. They explain exigency to the point where stakeholders' demands need urgent consideration, including demands that are time-sensitive and carry essential significance to a particular stakeholder group. To conclude, Mitchell et al. (1997) suggested a design with stakeholders grouping and precedence in a situation wherein stakeholder clusters are formed 
by analysing on the basis of three aspects: authority, authenticity and necessity. Nevertheless, stakeholder relevance theory concerns with authority, authenticity and urgency as separate traits. Therefore, it becomes all the more likely for a stakeholder to enjoy authority without worrying about authenticity or urgency from the administration. Authority alone does not suffice for a great level of stakeholder precedence. Similarly, an authentic demand noninclusive of authority and immediacy would carry much lesser relevance for the stakeholders. Thus, stakeholder relevance is linked with an increasing number of stakeholder traits assumed by the administrators.

\subsection{Stakeholder Theory and Tourism}

Growth of tourism, specifically policy-design and strategy involves the basic factor of stakeholders since sightseeing as a business, in its growth, has also seen parallel increase in complexity of the situation through stakeholders' interests and understanding of return on investment on growth of tourism. An innovative methodology for resolving these issues has been undertaken which recommends that all stakeholders who are concerned about or impacted by tourism behavior in a certain marketplace or locality, should together oversee the process of tourism. Likewise, Sautter and Leisen (1999) maintained that strategizing for tourism should include a complete comprehension of all relevant stakeholders carrying stakes in strategy, methodology and results of the activity. Jamal and Getz (1995) suggested that the viewpoint of stakeholders pertaining to growth of tourism activity is the basis, which leads to growth of tourism. Stakeholders might differ in these viewpoints as they carry diverse ethical convictions concerning subjects they are dealing with. Hardy and Beeton (2001) maintained that ethical convictions involve results, objectives, pursuits, ideologies, that might undergo transition according to human understanding over time and they affect authoritative decision making concerning policies largely. Thus, stakeholders carry diverse ethical convictions, which affect their viewpoints on advancement; therefore, the strategists must take into account the interests of all relevant stakeholders (Hardy and Beeton, 2001; Inskeep, 1991).

Inculcating stakeholders' perspectives lead to enhanced learning, which helps overcoming friction. Specifically, stakeholders' recognition and involvement is the primary initiative that leads to collaborating with local population and cooperation in the sector. (Hardy and Beeton, 2001; Yuksel et al., 1999). The ideas of stakeholder theory, when put into practice, need strategizing for coming to a conclusion, and remaining committed to the viewpoints of different stakeholder groups that are primary participants from the tourism industry (Sautter and Leisen, 1999). The next step that the stakeholder theory advances towards is involvement of different stakeholder groups for promoting steady growth of tourism in areas where four stakeholder groups are involved: inhabitants, executives, government functionaries and tourists (Byrd et al., 2009).

\section{Research Methodology}

\subsection{Sampling and Data Collection}

This paper aimed at analysing the factors affecting the stakeholders' support for sustainable tourism development in Shahat City, and identifying the tourism development trends, to analyse and understanding the attitudes, fears, as well as the hopes, those local stakeholders have concerning such developments through the application of scientific procedures. The sample of this study consists of four groups of stakeholders in Shahat city. Four stakeholder groups, such as domestic tourists, international tourists, residents living in the tourism destinations, residents working in the tourism industry were selected based on their relative dominance in terms of their level of stake and influence in the tourism industry. Nonprobability convenience sampling was conducted for this study. Prior to the distribution of main questionnaire, representatives from respondents were contacted via a sample of the 
questionnaire which was pilot tested in the research content for necessary revision. As a result of the pilot test, no reason was found to change the survey instrument. The researcher made to distribute all questionnaires along with a cover letter and information assuring confidentiality, and tried to collect data on a face-to-face basis. All of the questionnaires were conducted on a face to face. Of the 380 questionnaires, 356 were completed and usable for further data analysis, yielding a response rate of $93 \%$.

\subsection{Measures and Data Analysis}

The questionnaire used in this research was adopted from previous studies (Alexander, 2000; Bramwell, et al, 1996; Choi and Sirakaya, 2005; Hunter, 1997; Makawi, 2001; Neal and Gursoy, 2008; Sharpley, 2000; Slee and Snowdon, 1997; Southgate and Sharpley, 2002; Swarbrooke, 2000; UNEP/WTO, 2010; Wahab, 1997; WTO, 2008). The questionnaire used as a research tool for this study consists of two parts. In the first section there are 6 dimensions such as adequacy of tourist resources, perceptions toward tourism, level of involvement, environmental attitudes, economical attitudes, and Social attitudes. In the second part there are 4 questions such gender, age, marital status, educational status. The questionnaire was prepared both in Arabic and English and a 5 point likert scale was used. Accordingly, the statements in the questionnaire are arranged so as to be evaluated as ' 1 strongly disagree, '2- disagree, '3-undecided, '4-agree, '5-strongly agree'.

The Statistical Package for Social Sciences version 21 was used to analyze the data. As for statistical techniques, first reliability (Cronbach's alpha) value and validity tests were conducted. Next, mean score descriptive analysis was employed to observe average responses of the respondents who participated in this survey.

\section{Results}

\subsection{Describtive Statistics}

General characteristics of the respondents is presented in the table 1. The demographic characteristics of respondents were an important variable used by planners and development policy-makers when designing development plans. The study of these characteristics is expected to assist in the assessment of stakeholder attitudes on sustainable tourism development in the Shahat City. The table 1 demonstrates that $76.6 \%$ are males, $74.4 \%$ are married, $28.3 \%$ are between the ages of 36-45 and 33.3\% have secondary school level of education. Along with this, Table 2 shows normality test results. According to Hair et al. (1998), skewness values from -1 to 1 and the values of the kurtosis within -3 to +3 indicate an acceptable range of normality while the values that fall outside the range of skewness and kurtosis indicate a large departure from normal distribution. Thus, Table 2, shows that the values of skewness and kurtosis of all variables fall within the accepted area. It can be deduced that all the data for "AS. Model" follows the normal distribution. This means that it will use parametric tests in this study where it is the best of the non-parametric tests giving more accurate results, because the non-parametric tests depend on the level of the sample and not the actual value thereof (Field, 2000).

Table 1: Characteristics of the sample (tourists and residents).

\begin{tabular}{lccccc}
\hline Characteristics & $\begin{array}{c}\text { Domestic } \\
\text { Tourists }\end{array}$ & $\begin{array}{c}\text { International } \\
\text { Tourists }\end{array}$ & $\begin{array}{c}\text { Residents Living } \\
\text { in the tourism } \\
\text { destinations }\end{array}$ & $\begin{array}{c}\text { Residents } \\
\text { Working in the } \\
\text { tourism Industry }\end{array}$ & All stakeholders \\
& (DT) & (IT) & (RLD) & (RWI) & (AS)
\end{tabular}




\begin{tabular}{|c|c|c|c|c|c|c|c|c|c|c|}
\hline & $N=141$ & $\%$ & $\mathrm{~N}=35$ & $\%$ & N 144 & $\%$ & $\mathrm{~N}=36$ & $\%$ & $\mathrm{~N}=356$ & $\%$ \\
\hline \multicolumn{11}{|l|}{ Gender : } \\
\hline Male & 95 & 67.3 & 21 & 55.3 & 128 & 88.8 & 29 & 80.5 & 273 & 76.6 \\
\hline Female & 46 & 32.7 & 14 & 44.7 & 16 & 11.2 & 7 & 19.5 & 83 & 23.4 \\
\hline \multicolumn{11}{|l|}{ Marital status: } \\
\hline Marriage & 96 & 68.1 & 6 & 17.1 & 138 & 95.8 & 25 & 69.4 & 265 & 74.4 \\
\hline Single & 45 & 31.9 & 29 & 82.9 & 6 & 4.2 & 11 & 30.6 & 91 & 25.6 \\
\hline \multicolumn{11}{|l|}{ Age: } \\
\hline $18-25$ & 18 & 12.7 & 0 & 0 & 13 & 9.2 & 8 & 22.4 & 39 & 10.9 \\
\hline $26-35$ & 31 & 21.9 & 4 & 11.5 & 28 & 19.4 & 17 & 47.2 & 80 & 22.4 \\
\hline $36-45$ & 53 & 37.9 & 11 & 31.4 & 32 & 22.2 & 5 & 13.8 & 101 & 28.3 \\
\hline $46-55$ & 21 & 14.8 & 18 & 51.4 & 44 & 30.5 & 6 & 16.6 & 89 & 25.1 \\
\hline Above 55 & 18 & 12.7 & 2 & 5.7 & 27 & 18.7 & 0 & 0 & 47 & 13.3 \\
\hline \multicolumn{11}{|l|}{ Education: } \\
\hline No formal education & 24 & 17.2 & 0 & 0 & 3 & 2.1 & 2 & 5.5 & 29 & 8.2 \\
\hline Primary school & 26 & 18.4 & 4 & 11.4 & 49 & 34.2 & 6 & 16.6 & 85 & 23.8 \\
\hline Secondary school & 23 & 16.3 & 9 & 25.7 & 72 & 50 & 14 & 38.8 & 118 & 33.3 \\
\hline Tertiary education & 12 & 8.5 & 6 & 17.3 & 4 & 2.7 & 5 & 13.8 & 27 & 7.5 \\
\hline Bachelor's Degree & 47 & 33.3 & 8 & 22.8 & 14 & 9.7 & 8 & 22.6 & 77 & 21.6 \\
\hline Above Bachelor's & 9 & 6.3 & 8 & 22.8 & 2 & 1.3 & 1 & 2.7 & 20 & 5.6 \\
\hline
\end{tabular}

After conducting the field study, the researcher obtained four different types of data that enabled the extraction of seven different models, which are as follows:

1. Domestic Tourism (DT. Model).

2. International Tourism (IT. Model).

3. Residents Who Live in the Tourist Destinations (RLD. Model).

4. Residents Who Work in the Tourism Industry (RWI. Model).

In addition to three other models:

5. All Tourists Groups (AT. Model), which include (DT + IT).

6. All Residents Groups (AR. Model), which include (RLD+ RWI).

7. All Stakeholder Groups (AS. Model), which include (DT+ IT+ RLD+ RWI).

The researcher dealt with the models seven "AS Model" in this paper. Because those models is not a part of the study, but used as a cofactor to identify the nature of the data, they are not that important as to be placed here. The researcher reviewed the distribution type in the seven model "AS Model" and the table 2, below present the descriptive statistics resulting from the data collected from a random sample of the seven categories mentioned above in Shahat City for study variables relating to the study question. The tables include the mean as a measure of spread of distribution, maximum and minimum values, and skewness and kurtosis values to verify their nature for each variable.

Table 2: Normality test (AS model).

\begin{tabular}{lcccccc}
\hline The Variables & Mean & $\begin{array}{l}\text { Std. } \\
\text { Deviation }\end{array}$ & Min & Max & Skewness & Kurtosis \\
\hline $\mathrm{X} 1_{\mathrm{AS}}$ & 4.3703 & 0.281 & 3.67 & 5.00 & 0.025 & -0.485 \\
$\mathrm{X} 2_{\mathrm{AS}}$ & 4.2822 & 0.290 & 3.50 & 5.00 & -0.054 & -0.237 \\
$\mathrm{X} 3_{\mathrm{AS}}$ & 4.0371 & 0.382 & 3.00 & 5.00 & 0.068 & -0.108 \\
$\mathrm{X} 4_{\mathrm{AS}}$ & 4.4126 & 0.280 & 3.50 & 5.00 & -0.329 & -0.060 \\
$\mathrm{X} 5_{\mathrm{AS}}$ & 4.6068 & 0.238 & 3.67 & 5.00 & -0.493 & 0.374 \\
$\mathrm{X} 6_{\mathrm{AS}}$ & 4.4874 & 0.257 & 3.67 & 5.00 & -0.029 & -0227 \\
$\mathrm{Y}$ & 4.4181 & 0.290 & 3.17 & 5.00 & -0.230 & 0.422 \\
\hline
\end{tabular}

\subsection{Frequency Analysis}

As people's perceptions differ from person to person, it is very natural that the researcher obtained different answers to items that make up the scale of study which lead to different 
frequencies that can be used in the comparison between the different groups. That is discussed in the following table 3, which shows the frequencies of the attitudes of all stakeholder groups to the various key variables themes.

Table 3: Frequencies table of the views of all stakeholder groups (AS).

\begin{tabular}{|c|c|c|c|c|c|c|c|c|}
\hline \multicolumn{3}{|c|}{ Variable } & \multirow{2}{*}{ 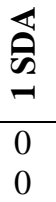 } & \multirow{2}{*}{$\begin{array}{l}\underset{\sim}{\sim} \\
0 \\
0\end{array}$} & \multirow{2}{*}{$\begin{array}{l}\mathbf{Z} \\
\boldsymbol{m}\end{array}$} & \multirow{2}{*}{$\begin{array}{c}\varangle \\
\\
\\
\end{array}$} & \multirow{2}{*}{ 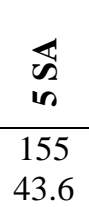 } & \multirow{2}{*}{ 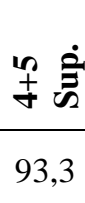 } \\
\hline $\mathrm{X} 1_{\mathrm{AS}}$ & Adequacy of tourist resources & F & & & & & & \\
\hline $\mathrm{X} 2_{\mathrm{AS}}$ & Perception toward sustainable development & $\begin{array}{l}\% \\
\mathrm{~F} \\
\%\end{array}$ & $\begin{array}{l}0 \\
0 \\
0\end{array}$ & $\begin{array}{l}0 \\
0 \\
0\end{array}$ & $\begin{array}{l}6.7 \\
28 \\
7.8\end{array}$ & $\begin{array}{r}49.7 \\
190 \\
533\end{array}$ & $\begin{array}{c}43.6 \\
138 \\
387\end{array}$ & 92,2 \\
\hline $\mathrm{X} 3_{\mathrm{AS}}$ & Involvement in tourism development & $\begin{array}{l}\mathrm{F} \\
\%\end{array}$ & $\begin{array}{l}0 \\
0\end{array}$ & $\begin{array}{c}1 \\
0.28\end{array}$ & $\begin{array}{c}70 \\
19.6\end{array}$ & $\begin{array}{r}200 \\
56.3\end{array}$ & $\begin{array}{c}85 \\
23.8\end{array}$ & 80,1 \\
\hline $\mathrm{X} 4_{\mathrm{AS}}$ & Environment attitudes & $\begin{array}{l}\mathrm{F} \\
\%\end{array}$ & $\begin{array}{l}0 \\
0\end{array}$ & $\begin{array}{l}0 \\
0\end{array}$ & $\begin{array}{l}15 \\
4.3\end{array}$ & $\begin{array}{l}180 \\
50.5\end{array}$ & $\begin{array}{c}161 \\
45.2\end{array}$ & 95,7 \\
\hline $\mathrm{X} 5_{\mathrm{AS}}$ & Economic attitudes & $\begin{array}{l}\mathrm{F} \\
\%\end{array}$ & $\begin{array}{l}0 \\
0\end{array}$ & $\begin{array}{l}0 \\
0\end{array}$ & $\begin{array}{c}2 \\
0.5\end{array}$ & $\begin{array}{r}136 \\
38.2\end{array}$ & $\begin{array}{l}218 \\
61.3\end{array}$ & 99,5 \\
\hline $\mathrm{X} 6_{\mathrm{AS}}$ & Social attitudes & $\begin{array}{l}\mathrm{F} \\
\%\end{array}$ & $\begin{array}{l}0 \\
0\end{array}$ & $\begin{array}{l}0 \\
0\end{array}$ & $\begin{array}{c}5 \\
1.4\end{array}$ & $\begin{array}{l}172 \\
48.3\end{array}$ & $\begin{array}{c}179 \\
50.3\end{array}$ & 98,6 \\
\hline $\mathrm{Y}_{\mathrm{AS}}$ & Support of sustainable tourism development & $\begin{array}{l}\mathrm{F} \\
\%\end{array}$ & $\begin{array}{l}0 \\
0\end{array}$ & $\begin{array}{l}0 \\
0\end{array}$ & $\begin{array}{r}14 \\
3.9\end{array}$ & $\begin{array}{r}180 \\
50.6\end{array}$ & $\begin{array}{l}162 \\
45.5\end{array}$ & 96,1 \\
\hline
\end{tabular}

Note: $\mathrm{N}$ 356. Strongly Disagree (SDA=1); Disagree ( $\mathrm{DA}=2)$; Neutral $(\mathrm{N}=3)$; Agree ( $\mathrm{A}=4)$; Strongly Agree $(\mathrm{SA}=5)$.

According to the data in table 4, the percentage of supporters for sustainable tourism development $\left(\mathbf{Y}_{\mathbf{A S}}\right)$ was $96.1 \%$, which indicates that the sustainable tourism development in the City gets great support from all stakeholder groups. Through the analysis, the researcher noted that there is support in varying degrees from all stakeholders for sustainable tourism development in the Shahat City, but there are some differences about the order of the independent variables that affect this support.

Table 4: Support sustainable tourism development in the Shahat City according to the sections and stakeholder groups' percentage.

\begin{tabular}{|c|c|c|c|c|c|c|c|c|c|}
\hline & \multicolumn{8}{|c|}{ Stakeholders group (tourist \& Residents) } \\
\hline & & \multirow{2}{*}{$\begin{array}{c}1 \\
\text { DT } \\
\mathrm{N}: 141 \\
92.6\end{array}$} & \multirow{2}{*}{$\begin{array}{c}2 \\
\mathbf{I T} \\
\mathrm{N}: 35 \\
85.8\end{array}$} & \multirow{2}{*}{$\begin{array}{c}3 \\
\text { RLD } \\
\mathrm{N}: 144 \\
94.5\end{array}$} & \multirow{2}{*}{$\begin{array}{c}4 \\
\mathbf{R W I} \\
\mathrm{N}: 36 \\
100\end{array}$} & \multirow{2}{*}{$\frac{\text { Mean }}{93.2}$} & \multirow{2}{*}{$\begin{array}{c}1+2 \\
\text { AT } \\
\mathrm{N}: 176 \\
90.8\end{array}$} & $\begin{array}{l}3+4 \\
\mathbf{A R} \\
180\end{array}$ & \multirow{2}{*}{$\begin{array}{c}1 \text { to } 5 \\
\text { AS } \\
\mathrm{N}: 356 \\
93.3\end{array}$} \\
\hline \multicolumn{2}{|c|}{$\begin{array}{l}\text { Group } \\
\text { Sections } \\
\text { X1 Adeguacy of tourist resources }\end{array}$} & & & & & & & 056 & \\
\hline \multirow{2}{*}{\multicolumn{2}{|c|}{$\begin{array}{ll}\mathrm{X} 1_{\mathrm{AS}} & \text { Adequacy of tourist resources } \\
\mathrm{X} 2_{\mathrm{AS}} & \text { Perception toward sustainable } \\
\text { development }\end{array}$}} & & & & & & & & \\
\hline & & 91.5 & 91.2 & 91.1 & 100 & 93.4 & 91.4 & 92.7 & 92.2 \\
\hline $\mathrm{X} 3_{\mathrm{AS}}$ & $\begin{array}{l}\text { Involvement in tourism } \\
\text { development }\end{array}$ & 88.7 & 54.4 & 72.8 & 100 & 78.9 & 81.9 & 78.3 & 80.1 \\
\hline \multirow{3}{*}{$\begin{array}{l}\mathrm{X} 4_{\mathrm{AS}} \\
\mathrm{X} 5_{\mathrm{AS}} \\
\mathrm{X} 6_{\mathrm{AS}} \\
\text { Mean }\end{array}$} & Environment attitudes & 92.8 & 88.5 & 100 & 100 & 95.3 & 91.5 & 100 & 95.7 \\
\hline & Economic attitudes & 100 & 94.3 & 100 & 100 & 98.5 & 98.8 & 100 & 99.5 \\
\hline & Social attitudes & 98.4 & 91.5 & 100 & 100 & 97.8 & 97.2 & 100 & 98.6 \\
\hline \multicolumn{2}{|c|}{ Mean } & 94 & 84.2 & 93 & 100 & 92.8 & 91.9 & 94.4 & 93.2 \\
\hline $\mathrm{Y}_{\mathrm{AS}}$ & $\begin{array}{l}\text { Support of sustainable tourism } \\
\text { development }\end{array}$ & 92.6 & 91.4 & 100 & 100 & 96 & 92.5 & 100 & 96.1 \\
\hline
\end{tabular}


Through what has been reviewed in this study, the researcher noted some important points that have been summarized as follows:

- According to the view of stakeholders, tourism resources located in the Shahat City are sufficient to establish a sustainable tourism development in the City, where the mean of approval rates of this section has achieved 93.2\%.

- Perceptions of stakeholders towards tourism development in the Shahat City are very positive, where the mean of approval rates of this section has achieved $93.4 \%$.

- The level of involvement of stakeholders in sustainable tourism development in the City is still under the general average, but it is positive where the mean of approval rates of this section has achieved $78.9 \%$.

- Environmental attitudes of stakeholders towards sustainable tourism development in the Shahat City are very positive, where the mean of approval rates of this section has achieved $95.3 \%$.

- Economic attitudes of stakeholders towards sustainable tourism development in the Shahat City are very positive, where the mean of approval rates of this section has achieved $98.5 \%$.

- Social attitudes of stakeholders towards sustainable tourism development in the Shahat City are very positive, where the mean of approval rates of this section has achieved $97.8 \%$.

- The support for sustainable tourism development in the Shahat City by the respondents is very positive, where the mean of approval rates of this section has achieved $96.1 \%$.

- The general average for supporting sustainable tourism development in the Shahat City has achieved 96\%; thus, all the sections have achieved higher rates than the general average, except the section on the level of involvement in development that has achieved a lower rate than the general average.

\section{Conclusion, Implications and Limitations}

The results in this study highlight the intersection of variables that affect in the attitudes of stakeholder on tourism development and their ultimate support for sustainable tourism development. Overall, the results of the study revealed that there are results encouraging the establishment of sustainable tourism development in the Shahat City, where an overwhelming majority of the participants in the study positive trends on the development of tourism in this City. All of these represent the support of sustainable tourism development in the City. The following sub-items will be discussed in these findings:

In the table 4, (X1) shows clearly that both tourists and residents consider that tourism resources in the City can be relied upon to the development of sustainable tourism in the City. Where the average of the support for tourism development for all stakeholders through this index was 93.3\%, (see table 4), but the results showed that all residents (AR) are more confident in the city's tourism resources than the all tourists (AT), This may be a natural consequence, because the residents may have better knowledge about the City and its tourist resources than the tourists. Thus, it can be said that all stakeholders are to an extent in harmony and agree that the tourism resources in Shahat City are reliable in terms of quantity and quality in establishment of a sustainable tourism development in the City. This is in line with what was confirmed by a lot of researchers, about the availability of tourism resources in 
a particular place which often stimulate stakeholders to the establishment of tourism projects in that place, according to the possibilities available. Where development may begin simple at first and then spreads rapidly in the later stages (BFSC, 2013; Butler, 2009).

The table 4, (X2) shows clearly that support for tourism development through the index "perceptions toward tourism" reached 92.2\%. This means that the stakeholders (tourists and residents) perceive that the benefits derived from tourism development in the Shahat City are greater than the costs. With regard to sustainable tourism development in the study area, there was a common perception amongst all stakeholders in terms of the benefits derived from tourism, with some differences in the motives of support for tourism development, where the tourism development in the Shahat City is currently operating in an unsustainable manner. Thus, it can be said that the perceptions of stakeholders toward tourism development are to an extent in agree and harmony that the tourism development in Shahat City is bringing many benefits to stakeholders, especially to the local residents, where there is a general feeling by stakeholders that the strengths of the tourism development in the City are bigger than the weaknesses, and that the tourism development is the saviour of the poor economic situation in the City.

From the table 4, (X3) reveals that "the level of participation in the development of tourism in the Shahat City" has reached $80.1 \%$ and the results showed that the participation of international tourists (IT) in tourism in the Shahat City was less positive than of domestic tourists (DT). While domestic tourists may vary the level of their participation in the development of tourism in the City. The results showed that the level of participation of residents working in the tourism industry (RWI) is more positive than the level of participation of residents living in the tourist destinations (RLD), (see table 4) ; This is very normal; clearly people working in the tourism industry are going to be participating more in it than those who don't. In general, the level of participation of tourists (AT) in tourism in the Shahat City is more positive than the level of participation of residents (AR), (see table 4). Again, this is predictable, the tourists are of course participating in the industry by being a tourist, but residents' participation will depend on whole array of other factors in their lives.

The achievement the sustainable forms of tourism is the responsibility of all relevant stakeholders, including the Government at all levels, the private sector, international organizations, tourists, environmental groups, men and women citizens in tourism, countries of destination and countries of origin (Choi and Sirakaya, 2005). Jamieson and Jamal (1997) argued that participation of stakeholder is required in the process of sustainable tourism development. Hunter (1997) points out that participation of stakeholder in the process of planning is the foundation of the sustainability paradigm. Thus, it can be said that there is a certain level of participation in the tourism development in the Shahat City by stakeholders if given opportunity, and this is a positive attitude in favour of sustainable tourism development in the City. Several studies have already revealed that, without creating opportunities for stakeholders to participate in the process of tourism development process, it will be very complex for them, especially the residents, to obtain adequate benefits from tourism development (Chuibamrong, 2011; Clancy, 1999; Long, 1991). The results showed that participants in the study expressed their enthusiasm to participate in tourism decision making at the Shahat City, but they face many challenges.

In the table 4, (X4) shows that the percentage of support for tourism development through this index has reached 95.7\%. In general, the results through this indicator showed that the residents (AR) are more positive than the tourists (AT). This may be due to the high positive ratios for each of the residents working in the tourism industry (RWI), and residents living in the tourist destinations (RLD). This is very normal and corresponds to the nature of the work, where some of residents have more attention than others in understanding the environmental attitudes related to tourism, and may be due to the contact types between the residents and 
tourists (direct or non-direct) and the degree of tourism pressure on the environment .The results showed that the environmental attitudes of International Tourists (IT) $88.5 \%$ are less positive than the environmental attitudes of Domestic Tourists (DT) $92.8 \%$ towards tourism in the Shahat City. This can be attributed to enthusiasm of domestic tourists to achieve significant environmental gains from two sides, because domestic tourists are at the same time residents as well.

Thus, it can be said that there are positive environmental attitudes by stakeholder participants in the study towards tourism in Shahat City; this is a positive attitude in favour of sustainable tourism development in the City. These positive environmental attitudes can be attributed to the strong correlation between the tourism and environment, where preservation of the environment means the sustainability of tourism. Therefore, these positions came to confirm the willingness of stakeholders in the preservation of the environment in the Shahat City to use it in tourism development. These positive environmental attitudes reflect the findings of several studies, such as Walpole and Goodwin (2001) who examined stakeholders' perspectives on protected area tourism and its effect on support for the Komodo National Park in Indonesia. Their results indicated almost agreed support for conservation of the park. Moreover, Bashir (2012) found that positive environmental attitudes by stakeholders towards tourism affected positively and directly on sustainable tourism development in Meknes city. The results showed that the economic attitude of international tourists $(94.3 \%)$ is less positive than the economic attitudes for the domestic tourists $(100 \%)$ towards tourism in the Shahat City. This may be attributed to domestic tourists enthusiastic to achieve significant economic gains from the economy of their country, while international tourists may be less attentive to the conditions of the local economy. The results showed as well that the percentage of support for tourism development by residents working in the tourism industry (RWI) and residents living in the tourist destinations (RLD) for both were more positive, see table 4. This may be due to the direct economic benefits that are obtained by residents working in the tourism industry (RWI) and residents living in the tourist destinations (RLD) as a result of the direct dealing with the tourism sector. Thus, it can be said that there are positive economic attitudes by stakeholder participants in the study towards tourism in Shahat City; this is a positive attitude in favour of sustainable tourism development in the City. These positive economic attitudes can be attributed to the wish of stakeholders in achieving economic gains to the residents. For example, the tourists should buy local products and use local services, as well as the transactions between the guest and the host must be direct, without any intervention from the intermediaries to realize the full benefit for the residents. These positive economic attitudes reflect the findings of several studies, such as Medeiros and Bramwell (1999) who found that the residents emphasized the economic impacts of tourism and its effective use to create jobs and benefit infrastructure for the region and communities.

Going through the table 4, (X6) shows it is clear that the percentage of support for tourism development through the index of "social attitudes towards tourism development," amounted to $(98.6 \%)$. In general, the results showed through this indicator that the resident (AR) $100 \%$ are more positive than the tourists (AT) $97.2 \%$ are. The results showed that the social attitudes for international tourists (IT) $91.5 \%$ are less positive than the social attitudes for domestic tourists (DT) $98.4 \%$ towards tourism in the Shahat City. Similar results were found on the economic attitudes that those working or living in tourism destinations (RWI \& RLD) were more positive. Thus, it can be said that there are positive social attitudes by stakeholder participants in the study towards tourism development in Shahat City; this is a positive attitude in favour of sustainable tourism development in the City. These social positive attitudes can be attributed to the need of stakeholders in achieving social gains to the residents. For example, the tourists have to respecting the culture and values of local 
residents, as well as the Local residents be supposed to treat fairly without exploitation of their needs.

Through the results that have been reviewed in previous discussion on supporting sustainable tourism development, it is clear that there is considerable support by residents and tourists for tourism development in the Shahat City, which emphasizes the possibility of the development of sustainable tourism in the City. In the table 4, $\left(\mathrm{Y}_{\mathrm{AS}}\right)$ shows that it is clear that the percentage of support for sustainable tourism development in the Shahat City has reached 98.1\%. In general, the results showed through this indicator that the support by all residents (AR) for tourism development in City is $100 \%$ that is greater than the support by all tourists (AT) for tourism development in the City $92.5 \%$. The results also showed that the support of international tourists (IT) $91.4 \%$ is less than the support of domestic tourists (DT) $92.6 \%$ for tourism development in the Shahat City, but this may reflect their relatively limited engagement with the country. The overall pattern of support mirrors that of some of the individual indicators of residents working in the tourism industry (RWI) or residents living in the tourism destinations (RLD) were supportive for sustainable tourism development. This support for sustainable tourism development by stakeholders in the Shahat City, reflects similar findings to many studies, such as: Knollenberg (2011) who found that $90 \%$ of the stakeholders support the sustainable tourism development in the state of North Carolina, through their positive attitudes toward tourism development in the state; Also Sassenberg (2009) found that stakeholders support the integration between tourism and aquaculture seafood in the region of Nelson in New Zealand, as a means to promote sustainable tourism. Medeiros and Bramwell (1999) have applied stakeholder theory to examine collaboration in tourism planning and policy making in Costa Dourada Project in Brazil. The results showed that many stakeholders have supported the tourism development by emphasizing the economic impact of tourism and its efficient use to create income, employment and infrastructure benefits for the region and communities.

There are also some studies that have revealed a lack of support for tourism development by stakeholders, such as, Drita and Alkida, (2009) in his research on comparisons of stakeholders' perception towards the sustainable tourism development and its impacts in Shkodra Region (Albania), revealed a decrease in support for tourism development in the city because of conflict among stakeholder groups. However, the majority of local residents generally were welcoming of tourism development. Manwa, (2003) applied stakeholder theory in a critical analysis of wildlife-based tourism in Zimbabwe. He found that there is very weak support for sustainable tourism development because of the absence of the participation of all stakeholders, where only the power brokers were beneficiaries at the expense of the hidden stakeholders, such as the poor and women who are considered traditional users of resources.

The cumulative results of this study demonstrate widely that there is a support by stakeholders for the development of tourism in the Shahat City. Thus, the main question for the study has been answered: "according to stakeholders' perceptions and their positive attitudes, there is a support by stakeholders for the development of tourism in the Shahat City. Consequently, there is a possibility for the establishment of sustainable tourism development in it".

Tourism is one of the world's major growing industries where tourist attractions are now more diverse and where new other choice types of sustainable tourism are beginning to spread. It preserves the environment and promotes the social and economic development of local communities and provides useful experiences for tourists. Therefore, when it comes to sustainable tourism development, It is necessary to take into consideration the idea that planning should be coordinated and in cooperation with all stakeholder that may or may be affected by this activity, by focusing particularly on the residents, who must be the firstly 
benefit from this development through the establishment of new companies; this will develop employment opportunities, which will help increase the standard of living for them. Thus they become able to find solutions for many of the problems.

Tourism development in the Shahat City is still in the exploration phase; therefore, this research is timely because it has measured the extent of stakeholders' support for tourism development early. The study results revealed the presence of strong support by stakeholders for tourism development in the City, which means that there is real potential for sustainable tourism development. This research will draw the attention of policy makers to the important tourism potential in the City, and give a large degree of trust and confidence for investors and decision-makers, besides providing as well good information for planners and investors which leads to draw good plans that help to stimulate the economy within the City, and establish new companies that will lead to increased employment opportunities, thereby increasing the standard of living for the residents.

This study is expected to serve as a basis for the developing of sustainable tourism in Shahat City in a more coherent, collaborative and sustainable manner by identifying resources and tourism potential available and soliciting the perceptions and attitudes of stakeholder who have demonstrated their support for the sustainable development of tourism in the city. In addition, this study can be used as a basis for the expansion and further research on stakeholders and sustainable tourism development in general, in the context of the Shahat City, any other city in Libya, or elsewhere in the world especially in developing countries. To achieve sustainable tourism development in the City, it is necessary to gain stakeholder satisfaction on an ongoing basis especially the local communities, and maintain the ecological balance as much as possible, but care must be taken of the emergence of strong competition in the market under incomplete conditions, especially in the early stages of the development process, because it leads to the elimination of small locally owned tourism businesses with the loss of local control over tourist development, where the sustainable tourism development goals will not be achieved as planned.

A key limitation of this study is the restriction to four stakeholder groups (Residents Working in Tourism Industry, Residents Living in the Tourist Destinations, International and Domestic Tourists,). Another factor by which the study was bounded is the limited number of variables (six variables examined in this research) are adequacy of tourist resources, perceptions toward tourism, level of involvement, environmental attitudes, economic attitudes, and social attitudes. Although there are many other variables which could also potentially influence support for Sustainable Tourism Development, the number of variables measured in this study was restricted in order to maintain the focus of the study. Additionally the study was delimited within the specific geographical and socio-cultural context in the Shahat City. So, the findings of this study should be considered only within the specific geographical and socio-cultural context. Thus, the results of this research may be limited in generalizability to residents of the Shahat City and tourists to the Shahat City, but it can be simulated and applied to other cities of a different nature inside or outside Libya.

\section{References}

Alexander, S. E. (2000). Resident attitudes towards conservation and black howler monkeys in Belize: the Community Baboon Sanctuary. Environmental Conservation, 27(4), 341350 . 
Baira, A. (2007). Public Policies for Administrative Development in Libya - a holistic perspective. Paper published in the book of First National Conference on Public Policy in Libya. Benghazi, Research Center, University of Benghazi.

Bashir, S. (2012). Stakeholders' Involvement in the Public Planning for development. Sustainable tourism development in the states of northern Morocco. Second Academic Forum for the development of the Arab Maghreb countries. (September, 2012). Rabat, Morocco.

BFSC.(2013). Tourism Cost And Benefits. Barcelona Field Studies Center S.L. Geography Field. Retrieved from http://geographyfieldwork. com//TourismProsCons.htm.

Bramwell, B., Henry, I., Jackson, G., Prat, A., Richards, G., \& Van der Straaten, J. (eds), (1996). Sustainable Tourism Management: Principles and Practice. Tilburg: Tilburg University Press, Tilburg.

Bryson, J. M., Cunningham, G. L., \& Lokkesmoe, K. J. (2002). What to do when stakeholders matter: the case of policy formulation for the African American men project of Hennepin County, Minnesota. Public Administration Review, 62(5), 568-584.

Butler R. W. (2009). Tourism in the future: Cycles, waves or wheels?. Futures, 41(6), 346-352.

Byrd, E. T. (2007). Stakeholders in sustainable tourism development and their roles: applying stakeholder theory to sustainable tourism development. Tourism Review, 62(2), 6-13.

Byrd, E. T., Bossley, H. E., \& Dronberger, M. G. (2009). Comparisons of stakeholder perceptions of tourism impact in rural eastern North Carolina. Tourism Management. 30(5), 693-703.

Charkham J. P. (1992). Corporate governance: lessons from abroad. European, Business Journal, 4(2), 8-16.

Choi, H. \& Sirakaya, E. (2005). Measuring residents' attitude toward sustainable tourism: Development of sustainable tourism attitude scale. Journal of Travel Research, 43(4), 380-394.

Choibamroong, T. (2011). A stakeholder approach for sustainable community-based rural tourism development in Thailand, Tourist Destination Governance: Practice, Theory and Issues, , CABI, Wallingford. 173-186.

CIA, (2006). Central Intelligence Agency Libya. (17 December 2016). Retrieved from http://www. cia.gov/cia/publication/factbook/. Elds/2060.

Claiborne, P. (2010). Community Participation in Tourism Development and the Value of Social Capital. The case of Bastimentos, Bocas Del Toro, Panamá. (Master Degree Project), No.2010: 84. University of Gothenburg.

Clancy, M. J. (1999). Tourism and development: Evidence from Mexico. Annals of Tourism Research, 26(1), 1-20.

Clarkson, M. R E. (1995). A stakeholder framework for analyzing and evaluating corporate social performance. Academy of management review, 20(1), 92-117.

Couret, D. G. (2008). Sustainability in developing and developed countries. Archit. Polit, 42, $1-5$.

Drita, K., and Alkida, H. (2009).Comparisons of stakeholders' perception towards the sustainable tourism development and its impacts in Shkodra Region (Albania). Turizam vol. 14 (1).

Field, D. J. (2000). Wavelets, vision and the statistics of natural scenes. Philosophical Transactions of the Royal Society of London A: Mathematical, Physical and Engineering Sciences, 357(1760), 2527-2542.

Freeman, R. E. (1984). Strategic Management: a Stakeholder Approach. Boston: Pitman.

Freeman, R. E. (2010). Strategic management: a stakeholder approach. Cambridge University Press, Cambridge.

Friedman A.L. \& Miles S. (2006). Stakeholders: theory and practice. Oxford University Press. 
Fusco, G., Luigi, N., \& Nijkamp, P. (2009). Cultural tourism and sustainable local development. Ashgate Publishing, Ltd.

GBTA, (2002). General Board for Tourism and Antiquities. Report on tourism problems. Presented to the Secretary of General Board for Tourism and Antiquities. Tripoli, Libya.

Gnan, L., Hinna, A., Monteduro, F., \& Scarozza, D. (2010). Corporate governance and management practices: stakeholder involvement, quality and sustainability tools adoption. Journal of Management \& Governance, 17(4), 907-937.

Graci, S. (2013). Collaboration and partnership development for sustainable tourism. Tourism Geographies, 15(1), 25-42.

Grimble, R., \& Wellard, K. (1997). Stakeholder methodologies in natural resource management: a review of principles, contexts, experiences and opportunities. Agricultural systems, 55(2), 173-193.

Hair, J. F., Anderson, R. E., Tatham, R. L., \& Black, W. C. (1998). Multivariate Data Analysis, ( $5^{\text {th }}$ ed), Prentice Hall International, London.

Hann, D. (2011). Stakeholder theory in finance: on the financial relevance of nonfinancial stakeholders.(unpublished doctoral thesis). Maastricht University.

Hardy, L., and Beeton, S. (2001). Sustainable tourism or maintainable tourism: Managing resources for more than average outcomes. Journal of Sustainable Tourism, 9(3), 168192.

Hawkins, D., \& Cunningham, J. (1996). It is "never-never land" when interest groups prevail: Disney's America project, Prince William County, Virginia, USA. Practicing responsible tourism: International case studies in tourism planning, policy, and development, 350-365.

Hunter, C. (1997). Sustainable tourism as an adaptive paradigm. Annals of Tourism Research, 24(4), 850-867.

Inskeep, E. (1991). Tourism planning: an integrated and sustainable development approach. Van Nostrand Reinhold.

Jamal, T. B., \& Getz, D. (1995). Collaboration theory and community tourism planning. Annals of Tourism Research, 22 (1), 186-204.

Jamieson, W., \& Jamal, T. (1997). Tourism planning and destination management. In C. Gee \& E. Fayos-Sola (Eds.), International tourism: a global perspective. (321-337). Madrid, Spain: World Tourism Organization.

Jwaili, M., Jones, E., \& Thomas, B. (2004, June). Small and medium-sized enterprises in the development of the Libyan Tourism Industry. In Proceedings of Tourism State of the Art II Conference.

Khalil, M. (2012). Overview of international development conferences. Education and development, Zahra library, Beirut.

Kitamura, Y., \& Hoshii, N. (2010). Education for sustainable development at universities in Japan. International Journal of Sustainability in Higher Education, 11(3), 202-216.

Knollenberg, W. (2011). Stakeholders' attitudes towards sustainable tourism development in coastal communities. (Master's thesis). Presented To the Faculty in Sustainable Tourism, Graduate School. East Carolina University.

Lepp, A. (2008). Attitudes towards initial tourism development in a community with no prior tourism experience: The case of Bigodi, Uganda. Journal of Sustainable Tourism, 16(1), 5-22.

LG, (1998). Libyan Tourism Master Plan 1998-2018. Libyan Government: Tripoli.

Lilly M. (2003). Taking the pulse of stakeholders. B To B [serial online]. March 10. 88(3):12. Available from: Business Source Complete, Ipswich, MA. Accessed October 25, 2017. 
Long, P. (1991). Government-industry-community interaction in tourism development in Mexico. In M. T. Sinclair, \& M. J. Stabler, The tourism industry: An international analysis, Wallingford: CAB International. 205-222.

Makawi, H. (2001).Tourism and local natural resource: a general overview of tourism in the east of Sudan. Faculty of Economic and Social Studies, University of Khartoum.

Manwa, H. (2003). Wildlife-based tourism, ecology and sustainability: a tug-of-war among competing interests in Zimbabwe. Journal of Tourism Studies, 14(2), 45-55.

Medeiros, A. L., \& Bramwell, B. (1999). Stakeholder assessment and collaborative tourism planning: The case of Brazil's Costa Dourada project. Journal of Sustainable Tourism, 7(3-4), 356-378.

Mensah, A. M., \& Castro, L. C. (2004). Sustainable resource use \& sustainable development: a contradiction. Center for Development Research, University of Bonn.

Mitchell, R K., Agle, B. R, \& Wood, D. J. (1997). Toward a theory of stakeholder identification and salience: Defining the principle of who and what really counts. Academy of Management Review, 22(4), 853-886.

Neal, J. D., \& Gursoy, D. (2008) . A multifaceted analysis of tourism satisfaction. Journal of Travel Research, 47(1), 53-62.

Ruhanen, H., \& Lisa, M. (2006). Sustainable tourism planning: an analysis of Queensland local tourism destinations. (Unpublished doctoral Thesis), School of Tourism, University of Queensland.

Sassenberg, (2009). The role of key stakeholders in sustainable tourism development: the case study of Nelson/Marlborough/Golden Bay in New Zealand, MA thesis submitted to Auckland University of Tecnology. Faculty of Applied Humanities.

Sautter, S.T., and Leisen, B. (1999). Managing stakeholders: a tourism-planning model. Annals of Tourism Research, 26(2), 312-328.

Supreme Commission for Tourism (2001). towards comprehensive and sustainable development of the tourism industry in Saudi Arabia, the future vision of the Saudi economy until 2018. Worksheet.

Selin, H. \& Chavez, G. (1995). Developing a collaborative model for environmental planning and management. Environmental Management, 19(2), 189-195.

Sharpley, R. (2000).Tourism and sustainable development: exploring the theoretical divide. Journal of Sustainable Tourism, 8(1), 1-19.

Sheehan, L. \& Ritchie, J. (2005). Destination stakeholders: exploring identity and salience. Annals of Tourism Research, 32(3), 711-734.

Slee, B., \& Snowdon, P. J. (1997). The economic impacts of alternative forms of rural tourism, Journal of Agricultural Economics, 48(2), 179.

Social and Economic Council (2000). Report draft for the contribution for renewing the national tourism, No. 16 , p. $56-57$.

Southgate, C.,\& Sharpley, R. (2002). Tourism, development and the environment. Tourism and development: Concepts and issues, 231-264.

Suchman, M. C. (1995).Managing legitimacy: Strategic and institutional approaches. Academy of Management Review, 20(3),571-610.

Swarbrooke, J. (2000). Tourism, economic development and urban regeneration: a critical evaluation. Developments in Urban and Rural Tourism Centre for Travel and Tourism, Sheffield Hallam University and University of Northumbria, Sunderland, 269-285.

Wahab, S. (1997). Tourism; Sustainable development. Routledge (London and New York), Book, Edited.

Walpole, M. J., \& Goodwin, H. J. (2001). Local attitudes towards conservation and tourism around Komodo National Park, Indonesia. Environmental conservation, 28(2), 160166. 
Wan, Y. K. P., \& Li, X. (2013). Sustainability of tourism development in Macao, China. International Journal of Tourism Research, 15(1), 52 - 65.

Weaver, D.B \& Lawton, L.J. (2007). Twenty years on: The state of contemporary ecotourism research. Tourism Management, (28), p 168.

WTO,(2010). Site of the World Tourism Organization. On the web: www.world-tourism.org.

Yuksel, F., Bramwell, B., \& Yuksel, A. (1999). Stakeholder interviews and tourism planning at Pamukkale, Turkey. Tourism Management, 20(3), 351-360. 